\title{
Measurement the Hounsfield Unit of Alginate Impression Material Using CT-Scan Equipment to Find Equility with The Human Body Tissue
}

\author{
Taat Guswantoro ${ }^{1 *}$, Astri Suppa Supratman ${ }^{2}$, Imelda Sakti Asih ${ }^{3}$
}

\author{
${ }^{1}$ Universitas Kristen Indonesia \\ ${ }^{2,3}$ Radiology Installation, Ken Saras Hospital, Semarang, Indonesia \\ *Corresponding Email: taat.guswantoro@uki.ac.id
}

\begin{abstract}
Imaging using CT Scan utilizes the nature of the material that can absorb X-rays so the intensity of X-rays that penetrate the material will be attenuated. The attenuation coefficient of the material will provide information on the physical properties of it, in the image produced by CT Scan, the attenuation coefficients of the material is related to the number of Hounsfield Unit (HU), Alginate impression material is an irreversible hydrocolloid molding material that will form a gel when reacted with water without heating treatment process. The nature of alginate gel is elastic and has a fast setting time, often used in the manufacture of dentures. Alginate scanning using CT scan can provide information on alginate gel equivalents with human body tissue by comparing the HU values obtained. Alginate impression material that has been set up by using water is formed with a size of $11 \mathrm{x} 11 \mathrm{~cm}$ with a thickness varying $5 \mathrm{~mm}, 7 \mathrm{~mm}$ and $9 \mathrm{~mm}$ and then scanned using CT Scan obtained an average $\mathrm{HU}$ of -51 , which is equivalent to soft tissue such as lipid or breast.
\end{abstract}

Keywords: Alginate, CT scan, Hounsfield Unit, Soft Tissue

\section{INTRODUCTION}

X-rays coming from the CT-Scan device penetrate a material, the intensity will attenuate that the amount of attenuation is proportional to the density of the material. The greater the density of the material, the more the intensity of the light absorbed, so that the intensity that manages to penetrate the object is weaker. The value of material density can be obtained from the CT-Scan image, ie the material density is proportional to the CT-Number value expressed in Hounsfield Unit (HU) size. HU is a unit of attenuation of $\mathrm{x}$-rays after passing through a material that describes the differences in an organ. CT Number 1000 corresponds to air, whereas CT Number 1000 corresponds to solid bone, and CT Number 0 corresponds to water (Benedict, 2004; Kainz, 2006; Rosenberg, 2008). Human body tissue has different densities so that each tissue will have a CT-Number that is different according to the attenuation coefficient of the tissue. Water is recommended as a material for determining the CT Number because water is more than $90 \%$ of the soft tissue constituents in the human body. Because the HU value of water is 0 , a network that has a density smaller than water will have a negative HU value (Setiabudi and Anam, 2012).
The image produced by the CT scan per pixel represents the magnitude of the $\mathrm{x}$-ray attenuation coefficient of a voxel (Setiabudi and Anam, 2012), in other words that each pixel contains density information from the organ that is imaged. Based on information from this pixel, the density of the organ to be measured can be determined. Utilization of HU can be used for measurement of jaw bone density (Yunus and Murtala, 2010), for measurement of bone tissue density (Celenk and Celenk, 2012; Lang, 2010; Schreiber et al., 2014; Whitehouse, 2020).

The amount of HU can also be used to determine the equality of material with body tissue. Utilization of this tissue equivalent material is for phantom and bolus on radiotherapy. Based on the HU value can be determined the value of the electron density of each material which is equivalent to the network. Based on the HU value obtained by Natural Rubber has equality with fat tissue (Supratman et al., 2018), Silicon Rubber has equality between soft tissue and hard tissue (Astuti et al., 2018) so that both Natural rubber and silicon rubber are both used as bolus radiotherapy. 
Natural rubber and silicon rubber have elastic and flexible properties and can be easily shaped to adjust the contours of a person's body, this is in accordance with the material requirements that can be used as bolus (Günhan et al., 2003; Kudchadker et al., 2002), while alginate has properties that are flexible, elastic and easily formed, but not yet used as a material that is equivalent to the tissue.

Alginate is an ingredient extracted from brown seaweed that has a polysaccharide group (Laksanawati et al., 2017), and is a hydrocolloid that can form a gel (Maharani et al., 2017). Alginate in the market is packaged in powder form which is often used as a denture molding material. Alginates can form a gel without heating like agar in general, this happens because of the reaction of $\mathrm{Na}$-Alginate solution with $\mathrm{Ca}$ salt, when mixed with water the $\mathrm{Na}$ position will be replaced by $\mathrm{Ca}$ and formed Gel (Husni et al., 2012; Maharani et al., 2017; Rasyid, 2005; Theresia Mutia, Rifaida Eriningsih, 2011).

The practical application of alginate is as an ingredient for printing dentures, because alginate has a relatively fast setting time and because it is made from natural ingredients it is not harmful to the patient even though the printing is inserted into the patient's mouth. Based on the properties of the alginate in this study tested the HU value of Alginate by using a CT-Scan device to determine its equality with human body tissues.

\section{MATERIAL AND METHOD}

\subsection{Sample Preparation}

The sample in this study was a mixture of Alginate powder mixed with water, with a ratio of 32 grams of powder mixed with $100 \mathrm{ml}$ of water, then stirred until the mixture became homogeneous. After the mixture has been homogeneous then poured into a mold measuring $11 \times 11 \mathrm{~cm}$ then pressed to remove air cavities in the dough and give thickness to the mold. In this sample preparation a homogeneous sample of $5 \mathrm{~mm}, 7 \mathrm{~mm}$ and $9 \mathrm{~mm}$ was obtained.

\section{$2.2 \quad$ Hounsfield Unit (HU) Measurement}

HU measurements were carried out by scanning samples using a CT-scan device performed at Ken Saras Hospital, Semarang Regency. The HU results obtained from the scanned images are then compared with the HU references from various tissues in the human body. Some of the HU values in human body tissue are as follows which is shown in table 1 (Chen et al., 2006; Madamesila et al., 2016; Mahon et al., 2020).

Table 1. HU values for some tissues

\begin{tabular}{|l|l|l|}
\hline No & tissue & HU \\
\hline 1 & Lung (LN-300) & -710 \\
\hline 2 & Lung (LN-450) & -600 \\
\hline 3 & Lipid (AP6) & -100 \\
\hline 4 & Breast & -40 \\
\hline 5 & Brain & 4 \\
\hline 6 & Liver (LV1) & 38 \\
\hline 7 & Water & 0 \\
\hline 8 & Bone (B200) & 120 \\
\hline
\end{tabular}

\section{RESULT AND DISCUSSION}

CT-Scan testing aims to obtain CT-Numbers from Alginate. The CT-Number value of this material will then be compared with the CT-Number value of soft tissues that are in the human body. This CT-Number value represents the density of the material or material used. By knowing the CT-Number value of this material, it can be estimated the density of the material is equivalent to a particular tissue, so that it can be used further as a Phantom of the appropriate tissue. Tests using CT-Scan can be seen in Figure 1.

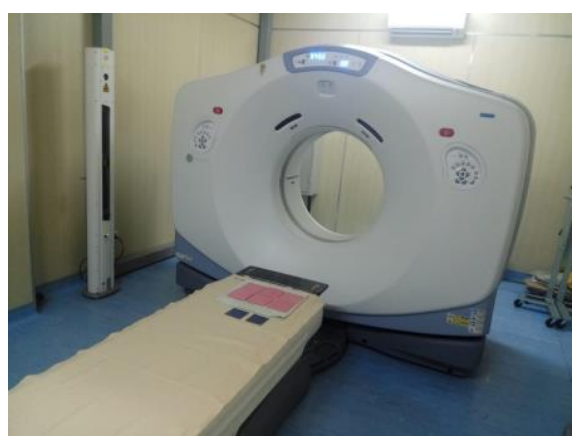

Figure 1. Testing sample using a CT-Scan equipment.

From the results of sample testing, the amount of CT-Number is presented in the following table 2.

Equivalence with soft tissue in the body is obtained by comparing the magnitude of CT-Number in table 1. Based on data obtained from research and compared with data from the table, it can be seen that Alginate has the closest equality with breast tissue, but alginate has a density that is slightly lower than the breast. From the data presented in table 1, Alginate also approaches fat tissue, alginate has a higher 
density than fat tissue. From these data it can be said that alginate has equality with breast tissue and fat tissue, but it is closer to breast tissue.

Table 2. Alginate test results using CT-Scan

\begin{tabular}{|l|l|l|}
\hline No & Thickness (mm) & CT-Number \\
\hline 1 & 5 & -43 \\
\hline 2 & 7 & -56 \\
\hline 3 & 9 & -53 \\
\hline Average & -51 \\
\hline
\end{tabular}

The HU of alginate as shown in the table 2 is negative, so it can be said that alginate has a density that is between air and water. In this category alginate can be said to have a density equivalent to soft tissue.

This results is because in making dough, alginate powder is mixed with water so that the chemical reaction process to form a gel, with a composition of more water, so there is a lot of water content in the alginate gel. As we know that in the fat and breast tissue which is soft tissue there is also a lot of water in each cell. Confirming its physical properties, alginate gel is elastic and elastic which is similar to the physical properties of breast tissue and fat.

\section{CONCLUSIONS}

Measurement of the $\mathrm{HU}$ value of alginate by using a CT-Scan device was obtained at -51 , which value is close to the $\mathrm{HU}$ value for breast tissue and fat tissue, so it can be said that Alginate has equality with breast tissue and fat tissue.

\section{ACKNOWLEDGMENTS}

The author would like to thank all the leaders of the Indonesian Christian University in Jakarta, the Chairperson of the Ken Saras Hospital in Semarang and colleagues at the Radiology Installation of Ken Saras Hospital in Semarang.

\section{REFERENCES}

Astuti, S.Y., Sutanto, H., Hidayanto, E., Jaya, G.W., Supratman, A.S., Saraswati, G.P., 2018. Characteristics of Bolus Using Silicone Rubber with Silica Composites for Electron Beam Radiotherapy. J. Phys. Its Appl. https://doi.org/10.14710/jpa.v1i1.3914

Benedict, S.H., 2004. Review of Radiation Oncology Physics: A Handbook for Teachers and Students. J. Appl. Clin. Med. Phys. https://doi.org/10.1120/jacmp.2021.25315

Celenk, C., Celenk, P., 2012. Bone Density Measurement Using Computed Tomography, in:
Computed Tomography - Clinical Applications. https://doi.org/10.5772/22884

Chen, H., Simpson, L., Morin, O., Pouliot, J., Sarkar, A., 2006. SU-FF-J-77: Image Quality Assessment for An Investigational Megavoltage Cone-Beam CT Device, in: Medical Physics. https://doi.org/10.1118/1.2240854

Günhan, B., Kemikler, G., Koca, A., 2003. Determination of surface dose and the effect of bolus to surface dose in electron beams. Med. Dosim. https://doi.org/10.1016/S09583947(03)00072-4

Husni, A., Subaryono, Pranoto, Y., Tazwir, Ustadi, 2012. Pengembangan Metode Ekstraksi Alginat dari Rumput Laut Sargassum Sp. Sebagai Bahan Pengental.

Agritech. https://doi.org/10.22146/agritech.9649

Kainz, K., 2006. Radiation Oncology Physics: A Handbook for Teachers and Students. Med. Phys. https://doi.org/10.1118/1.2201870

Kudchadker, R.J., Hogstrom, K.R., Garden, A.S., McNeese, M.D., Boyd, R.A., Antolak, J.A., 2002. Electron conformal radiotherapy using bolus and intensity modulation. Int. J. Radiat. Oncol. Biol Phys. https://doi.org/10.1016/S03603016(02)02811-0

Laksanawati, R., Ustadi, Husni, A., 2017. PENGEMBANGAN METODE EKSTRAKSI ALGINAT DARI RUMPUT LAUT Turbinaria ornata Rani. J. Pengelolaan Has. Perikan. Indones. https://doi.org/10.22146/agritech.9649

Lang, T.F., 2010. Quantitative Computed Tomography. Radiol. Clin. North Am. https://doi.org/10.1016/j.rcl.2010.03.001

Madamesila, J., McGeachy, P., Villarreal Barajas, J.E., Khan, R., 2016. Characterizing 3D printing in the fabrication of variable density phantoms for quality assurance of radiotherapy. Phys. Medica. https://doi.org/10.1016/j.ejmp.2015.09.013

Maharani, A.A., Husni, A., Ekantari, N., 2017. Karakteristik Natrium Alginat Rumput Laut Cokelat Sargassum fluitans Dengan Metode Ekstraksi Yang Berbeda. Jphpi.

Mahon, R.N., Ghita, M., Hugo, G.D., Weiss, E., 2020. ComBat harmonization for radiomic features in independent phantom and lung cancer patient computed tomography datasets. Phys. Med. Biol. https://doi.org/10.1088/1361-6560/ab6177

Rasyid, a., 2005. Beberapa Catatan tentang Alginat. Oseana.

Rosenberg, I., 2008. Radiation Oncology Physics: A Handbook for Teachers and Students. Br. J. Cancer. https://doi.org/10.1038/sj.bjc.6604224

Schreiber, J.J., Anderson, P.A., Hsu, W.K., 2014. Use 
of computed tomography for assessing bone mineral density. Neurosurg. Focus. https://doi.org/10.3171/2014.5.FOCUS1483

Setiabudi, W., Anam, C., 2012. Setiabudi, Wahyu, and Choirul Anam. "Pengaruh Perubahan Tegangan Tabung (kVp) Terhadap CT Number dan Uniformitasnya pada Pesawat CT Scan. J. Sains dan Mat. U 20, 77-80.

Supratman, A.S., Sutanto, H., Hidayanto, E., Jaya, G.W., Astuti, S.Y., Budiono, T., Firmansyah, M.A., 2018. Characteristic of natural rubber as bolus material for radiotherapy. Mater. Res.
Express. https://doi.org/10.1088/2053-1591/aad5ca

Theresia Mutia, Rifaida Eriningsih, R.S., 2011. Membran Alginat Sebagai Pembalut Luka Primer Dan Media. J. Ris. Ind.

Whitehouse, R.W., 2020. Computed Tomography, in: Medical Radiology. https://doi.org/10.1007/978-3540-68897-6_2

Yunus, B., Murtala, B., 2010. Pemanfaatan hounsfield unit pada CT-scan dalam menentukan kepadatan tulang rahang untuk pemasangan implan gigi. J. Dentomaxillofacial Sci. 